\title{
THE IMPROVEMENT OF STUDENTS' ACADEMIC WRITING THROUGH READING ABILITY USING COOPERATIVE INTEGRATED READING AND COMPOSITION (CIRC) MODEL
}

\author{
Rumiri Aruan \\ (rumiri.aruan@lecturer.unri.ac.id) \\ Faculty of Teachers Training and Education, Universitas Riau, Indonesia.
}

\begin{abstract}
This learning improvement study aims to improve teaching and learning outcomes in academic writing through reading ability by applying CIRC model. This research was conducted based on the problems that occur when students taking Academic Reading and Writing courses. Among the problems found is that students still find difficulties in writing a summary of the specified article. The research subjects were students in the fourth semester of the academic year 2018/2019. Before applying this method, the writer conducted a pre-test. The pre-test results showed that the students' writing summary skills were still low. The pre-test result was $2.77 \%$ of students scored very well, $19.43 \%$ got a good score, $27.77 \%$ of students scored moderately, $47.22 \%$ scored less, and $2.77 \%$ in the category of failure. The Classroom Action Research method is carried out in the application of the CIRC model which consists of two cycles, where each cycle took place in two meetings, and each cycle applied different learning activities. The results of the first cycle have shown changes in several assessment criteria, but the research was still being carried out into the second cycle. This was done to further strengthen learning by using the CIRC model. The percentage of student scores in the second cycle shows that $36.03 \%$ got a very good score, $33.33 \%$ got a good score, $30.55 \%$ got a sufficient score, and no more students scored less, and failed. From the above results can be concluded that the application of the CIRC model by the distribution of different discussion groups in each cycle affected learning outcomes. Thus the CIRC model can be considered to use in learning academic writing through reading ability in Academic Reading and Writing courses.
\end{abstract}

Keywords: Cooperative Integrated Reading and Composition (CIRC); summary writing; Learning Outcomes.

International Journal of Educational Best Practices (IJEBP)

Vol. 3 No. 2 October 2019

ISSN: 2581-0847

DOI: $10.31258 /$ ijebp.v3n2.p52-63 


\section{INTRODUCTION}

Students as learners state that writing academically is the hardest thing they do, especially when they ask to write a summary from the articles they read. The elements of writing summaries such as purpose and form, organization, style, and mechanics and spelling need good ability. Summary writing demanded ideas from students, where the intended idea can be obtained from the results of discussions with friends, lecturers, and from reading many articles. Without a lot of reading, learners will not be able to express ideas properly and pour them into writing academically. Academic Reading and Writing course give the chance to students practice it.

Academic Reading and Writing is one of the mandatory courses offered to students in the English study program of the Faculty of Teachers Training and Education of Riau University. The objectives of this course state the students should be able to write a summary, paraphrase, and draw conclusions from the readings presented. Various demands of the learning objectives of the Academic Reading and Writing courses require students to be proficient in writing the points mentioned above. This is certainly not easy for students as learners and lecturers as instructors who are also as facilitators to get to the learning objectives. The lecturer supporting the course must be more creative in choosing and determining learning models that will make students more enthusiastic in following the course.

The learning objectives of Academic Reading and Writing are allegedly not going to achieve the expected learning objectives, if the learning is still applying conventional learning strategies, meaning that lecturers only demand products from the learning outcomes implemented. Learning as mentioned above for some students less attractive and less impact on learning objectives. Interviews conducted with several students showed that they needed learning methods that motivated them to take Academic Reading and Writing courses to gain a good understanding, considering that this subject was difficult and boring compared to other skills such as listening and speaking, and reading

As already mentioned above, in Academic Reading and Writing courses students are required to be able to analyse readings or articles into writing, or students must be able to interpret the readings presented, is not an easy thing for students. The average results of the final exams of students who took the previous Academic Reading and Writing course in writing a summary were 61 . These results indicate that students are in a sufficient category. In other words, students are still not fully able to interpret the reading material given by lecturers properly. Therefore a strategy that can motivate students to succeed in this course is needed, as is the PAILKEM strategy (Uno and Mohammad, 2012) states that learning must be active, innovative, environmental, creative, effective and interesting. So that academic writing through reading becomes meaningful, effective, creative, and interesting learning, it can be done by choosing from many learning models. One way is to apply the

International Journal of Educational Best Practices (IJEBP)

Vol. 3 No. 2 October 2019

ISSN: 2581-0847

DOI: $10.31258 /$ ijebp.v3n2.p52-63 
Cooperative Integrated Reading and Composition (hereinafter referred to as CIRC) model in Academic Reading and Writing course. According to Shoimin (2014), CIRC is learning that combines reading and writing in groups. In this learning model students are in groups, discussing predetermined material, and finally, the present group works in the form of a summary or interpretation of readings from the material in writing. The task of the lecturer is to provide feedback on the results of the group discussions conducted. So, it is necessary to conduct research with the Classroom Action Research (CAR) method to prove whether through the implementation of CIRC can make learning outcomes and student activities in learning Academic Reading and Writing are in a good category. Therefore, the problems formulated as follows:

1. Can the CIRC model improve the students' academic writing through reading ability?

2. Can lecturers improve teaching-learning process using CIRC model?

This classroom action research that applies CIRC has the following objectives:

1. To find out whether CIRC model can improve the students' academic writing through reading ability.

2. To find out whether the application of CIRC model can improve the teachinglearning process in Academic Reading and Writing course.

Academic Reading and Writing course combine two different skills, namely productive skills (writing) and receptive skills (reading). Combining these two language skills is called integrated skills. Basically, integrated skills are to integrate one language skill with another language skill. Carols (1990) in Pardede (2017) outlines five advantages of integrated skills; first, skills integration provides continuity in teaching/program learning because in this approach tasks are closely related to each other; second, activities in the integrated skills approach can be designed to provide input before output; third, it provides realistic learning as skills integration allows for the development of four skills within a realistic communicative framework; fourth it provides chances to know and redeploy the language learned by students in different contexts and modes and it can be valuable because it allows for the recycling and revision of languages which has already been taught; fifth, skills integration increases confidence to a weaker or less confident learner.

According to Oshima and Ann Hague (2007) writing academically is different from creative writing. Writing academically pays attention to good and correct grammar, and organizes good ideas into written form. Harmer (1991) also classifies reading activities into six categories, namely, predictive skills, extracting specific information, getting the general picture, extracting detailed information, recognizing functions and discourse content, and deducing meaning from context. For students, the six skills above are not easy to do individually. They need a person or group to understand or practice the six skills mentioned above.

International Journal of Educational Best Practices (IJEBP)

Vol. 3 No. 2 October 2019

ISSN: 2581-0847

DOI: 10.31258/ijebp.v3n2.p52-63 
If related to one of the Cooperative Learning models, which requires active and creative students, individually and in groups, Academic Reading and Writing learning requires input/feedback not only from the lecturer, but also from his friends in the group. The CIRC learning model which is one of the Cooperative Learning models can facilitate the learning activities of Academic Reading and Writing.

CIRC is one of the group learning models. According to Sanjaya (2010) groups in the context of learning are face-to-face interactions of two or more individuals in the group, who have a shared responsibility in achieving learning objectives. Therefore in the learning process, each group member will work together to achieve common goals. Sanjaya also stated that there were four important elements in group learning, namely: (1) there were participants in the group; (2) the existence of group rules; (3) there is a learning effort for each group member; and (4) there are objectives that must be achieved. Furthermore (Harmer: 2009) in Chamisah (2013) suggests the strengths of the cooperative learning method as follows: (1) Groups can help the students develop communication skills, leadership skills, and cooperation skills; (2) Groups motivate the students who are bored; (3) Groups allow the students to work and interact independently without the necessary guided of the teacher, thus promoting the students independence; (4) It recognizes the old maximum that 'two heads are better than one' and in promoting cooperation helps the classroom to become a more relaxed and friendly place; (5) It is relatively quick and easy to organize; (6) Group can improve students' achievement. The above statement enables students who lack the understanding to be helped by students who already understand the learning topics presented. The weaknesses of the cooperative learning method are as follows; (1) Time consuming to organize a group work, (2) The teacher has less control over what students are doing in group work than in a normal class; (3) Group work in a large class will be noise; (4) Not all students enjoy it since they would prefer to focus on the teachers' attention rather than working in their groups; (5). During the group activity, the teacher cannot control the language used by the students; (6) The actual choice of pair group or group work can be problematic, especially if students frequently find themselves working with some they are not keen on. This weakness might be overcome by providing an interesting topic by the lecturer, as well as good classroom management so that learning objectives can be achieved. According to Durukan (2010), CIRC is a learning strategy designed to develop reading and writing skills at the secondary to tertiary level. Durukan's research results show that CIRC not only improves reading results but also enables it to be used in writing learning. Suprijono (2011) suggests the steps of CIRC learning as follows: a. forming groups with four heterogeneous members; $b$. the teacher gives discourse/clippings according to the topic of learning; c. students work together to read each other and find the main ideas and respond to discourse/clippings and written on a sheet of paper; d. present group results; e. the teacher makes conclusions together; $\mathrm{f}$. cover. In the Academic Reading and Writing course, the lecturer assigns students to look for articles related to learning English through the internet. The article is bundled or clipped. Each student looks for 10 articles. The last stage of this activity is the evaluation carried out by the lecturer. The evaluation will be carried out by evaluating paragraphs written by students based on the scoring rubric, which helps the lecturer to evaluate student writing.

International Journal of Educational Best Practices (IJEBP)

Vol. 3 No. 2 October 2019

ISSN: 2581-0847

DOI: $10.31258 /$ ijebp.v3n2.p52-63 
The rubric scoring used is analytic scoring rubric proposed by Brown and Bailey (1984) in Brown and Priyanvada (2010).

\section{METHODOLOGY}

The research subjects were 36 students of the English Study Program who took Academic Reading and Writing courses in the even semester 2018/2019. The study was conducted for one semester (6 months). This research is a Classroom Action Research, which was conducted in two cycles to see student learning outcomes and activities in participating in Academic Reading and Writing learning by using CIRC. Each cycle includes the stages of Planning, Action, Observation, and Reflection. This research design is an adaptation of the research design proposed by Kemmis and Taggart in Wiriaatmadja (Wiriaatmadja, 2007).

The sources of this research data were obtained from, students; to get data about learning outcomes and students activities in the learning process. Lecturer; to see the success rate of applying the CIRC strategy in Academic Reading and Writing course and students activities during the learning process. Collaborator; collaborators are intended as a source to see the implementation of CAR in a comprehensive way both from the students and lecturer side. In this study the data collection techniques were carried out as follows: Test; used to obtain data about student learning outcomes. Observation; used to collect data about students activities in Academic Reading and Writing learning that uses the CIRC strategy. Discussion; discussions were held between researchers and collaborators to reflect on the results of the CAR cycle.

Meanwhile, the data collection tools used are as follows: Test; using a set of reading topics where students make a summary or interpretation of the reading into writing in the form of paragraphs to measure students' understanding of the reading presented. This test will consist of the Pre-test, the first cycle learning outcomes test, and the second cycle learning achievement test. Observation; use observation sheets to measure the level of student and lecturer activity in the Academic Reading and Writing learning process. Discussion; using the observation sheet. In addition, performance indicators can be seen from the criteria determined as follows: College student. Students are declared successful if the test results reach a score of 4.0 / A according to academic regulations set by the Universitas Riau in 2018. Lecturer; Lecturer performance can be seen from the student attendance list and the results of observations.

In this study, there are two types of data, namely: Quantitative data. In this case, the value of student learning outcomes is analysed by descriptive statistical analysis, which is looking for the average value, and the percentage of learning success. Data obtained from students will use analytic scoring, as proposed by Brown and Priyanvada (2010) that in evaluating writing students should use analytic scoring to see the strengths and weaknesses of students in writing on content, organization, vocabulary, syntax, and mechanics. Next, Jacobs,

International Journal of Educational Best Practices (IJEBP)

Vol. 3 No. 2 October 2019

ISSN: 2581-0847

DOI: 10.31258/ijebp.v3n2.p52-63 
Zinkgraf, Wormuth, Hartfiel, and Hughey proposed the percentage of points above as follows: Content: 30, Organization: 20, Vocabulary: 20, Syntax: 25, Mechanics: 5, Total: 100. Qualitative data. In this case, the data/information obtained from the observation sheet, which will then be described in sentence form.

\section{RESULT AND DISCUSSION}

Pre Test was conducted before the implementation of CIRC was carried out. The aim of the Pre Test was to see the initial ability of the subject/students to write a summary in paragraph form. The results of Pre-Test writing summary show the ability to write summaries in various elements is still low. This can be seen from the summary results that require students to write purpose and form, organization, style, and mechanics. The Pre Test results were tabulated according to 2015 academic regulations issued by Universitas Riau.

Based on the criteria, the Pre-test data is obtained as shown in the following chart:

Chart 1. Pre-Test Result

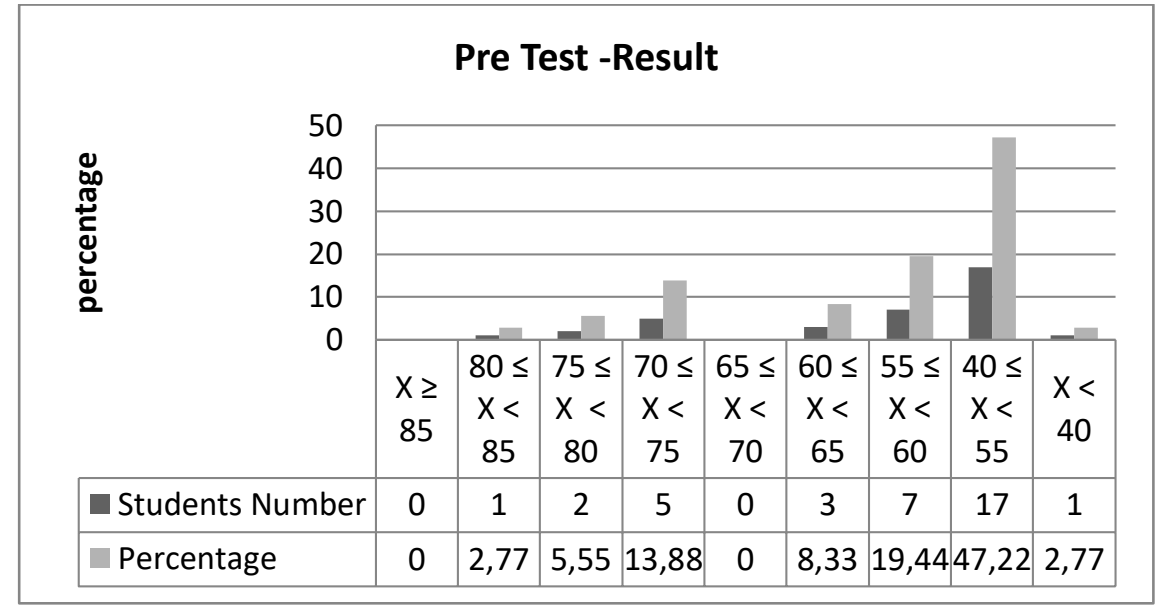

If we observe at the table above, the percentage of students' pre-test results has not good yet. The percentage of students who got "very-good" grades was only $2.77 \%$, while the percentage who got fewer marks was $47.22 \%$. The table above shows that the implementation of the learning strategy needs to be implemented, in this case, the CIRC learning model.

International Journal of Educational Best Practices (IJEBP)

Vol. 3 No. 2 October 2019

ISSN: 2581-0847

DOI: 10.31258/ijebp.v3n2.p52-63 


\section{Application of CIRC in Cycle 1}

In Cycle 1, the lecturer applied learning scenarios that have been designed in Lesson Plan. In this cycle, the writer applied the CIRC steps in two meetings, wherein each meeting each group discussed one different article. The article was about English language teaching skills, namely Listening, Speaking, Reading and Writing. The article discussed was chosen by the lecturer. At the end of the discussion, the students in the group were assigned to make a summary of the articles that had been discussed. Each group consists of three students, which determined by the lecturer randomly. While each group did discussion, the lecturer gave feedback, or answered questions from the group that was discussed. The learning process is observed using prepared observation sheets. The results of observations made on students showed the level of activity in group work was good, although in some groups there were still students who did not participate in the group, while some were less focused or lacked concentration on the article being discussed. While the observations made on the lecturer showed that the lecturer has acted as an adequate facilitator accompanied by giving feed-back in general, at each meeting. The collaborator did the observation by checking the observation sheets, to observe the learning process. In this step, the results of the individual summary are analysed at two meetings, based on predetermined criteria. If we look closely at the data obtained in cycle 1 , it shows a significant improvement compared to the Pre -Test results. The intended improvement is more clearly seen after compared to the criteria set by the Riau University in 2015, as shown in the following chart:

Chart 2. The Result of Cycle 1

\begin{tabular}{|c|c|c|c|c|c|c|c|c|c|c|}
\hline \multicolumn{11}{|c|}{ Cycle 1 Result } \\
\hline \multirow{3}{*}{ 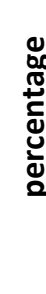 } & \multirow{3}{*}{$\begin{array}{r}25 \\
20 \\
15 \\
10 \\
5 \\
0\end{array}$} & & & & & & & & -1 & \\
\hline & & -1 & 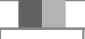 & & $\bar{n}$ & 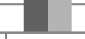 & $=$ & $=$ & 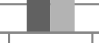 & -1 \\
\hline & & $\begin{array}{l}x \geq \\
85\end{array}$ & $\begin{array}{c}80 \leq \\
x< \\
85\end{array}$ & $\begin{array}{c}75 \leq \\
x< \\
80\end{array}$ & $\begin{array}{c}70 \leq \\
x< \\
75\end{array}$ & $\begin{array}{c}65 \leq \\
X< \\
70\end{array}$ & $\begin{array}{c}60 \leq \\
X< \\
65\end{array}$ & $\begin{array}{c}55 \leq \\
X< \\
60\end{array}$ & $\begin{array}{c}40 \leq \\
X< \\
55\end{array}$ & $\begin{array}{l}X< \\
40\end{array}$ \\
\hline & mber & 1 & 5 & 8 & 4 & 6 & 2 & 3 & 6 & 1 \\
\hline & & 2,77 & 13,88 & 22,22 & 11,11 & 16,66 & 5,55 & 8,33 & 16,66 & 2,77 \\
\hline
\end{tabular}

The chart above shows that the learning outcomes implemented in Cycle 1 have shown an increase in learning outcomes in several assessment criteria. Significant changes were seen in the evaluation criteria that were lacking, from 47.22 per cent in the Pre-Test, increasing to 16.66 per cent. This change might occur due to several things including the application of group discussion which caused students who lack understanding of the articles discussed with the group to be helped. However, the discussion between collaborator and researcher decided that it was necessary to continue the application of CIRC to Cycle 2 because there were still students who were under Unri's criteria.

International Journal of Educational Best Practices (IJEBP)

Vol. 3 No. 2 October 2019

ISSN: 2581-0847

DOI: 10.31258/ijebp.v3n2.p52-63 


\section{The Application of Cycle 2}

The research team made the next Academic Reading and a Writing learning plan based on the results of reflection in Cycle 1. The results of discussions with a collaborator that all group members in Cycle 1 will be overhauled. In other words, the number of groups is fixed, the number of group members is fixed, but the personnel change completely. A total overhaul of group members is intended so that students do not get bored with the same group members at each meeting. Reforming is also intended so that students have good interpersonal relationships with all group members. In Cycle 2, students in their groups were free to choose articles from articles owned by all students. Each group is given the opportunity first to choose the article to be discussed. Again the lecturer carries out Academic Reading and Writing learning based on the learning plan as a result of the reflection of Cycle 1, namely by Implementing Lesson Plan steps that are similar to steps contained in Cycle 1. In cycle 2, two meetings are also applied. It's just that in cycle 2; the instructions given by the lecturer are slightly different compared to in cycle 1, where students are instructed to read articles chosen by each group. They are very free to choose one of the 180 available articles.

The research team observed the Academic Reading and Writing learning process. In Cycle 2, collaborators also observed students and lecturers on the observation sheets that have been prepared. The observations of students indicated that students were more active and creative when compared to the results of observations of Cycle 1. This is suspected because there was a total overhaul of the members of the discussion group, as well as the freedom to choose articles to be discussed. In this second cycle, the lecturer still gave general feedback, but this time feedback was also given to groups and individuals. The research team reflected again on the implementation of Cycle 2, in the form of evaluating the Academic Reading and Writing learning process. The data obtained in this cycle shows satisfying results, as seen in the following Chart:

Chart 3. The Result of Cycle 2

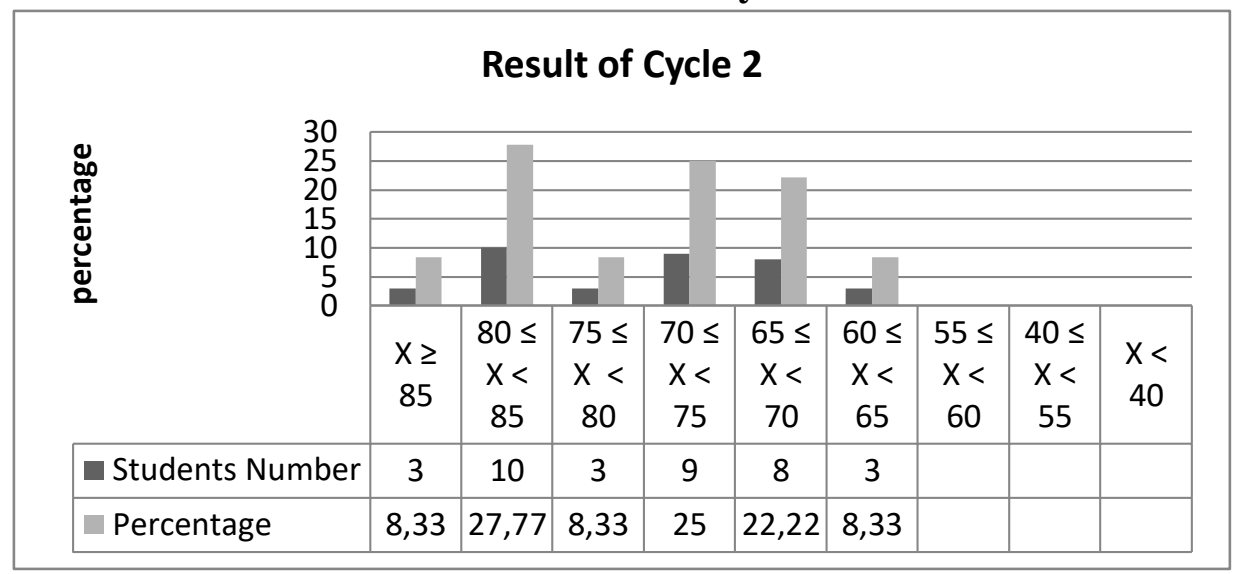

International Journal of Educational Best Practices (IJEBP)

Vol. 3 No. 2 October 2019

ISSN: 2581-0847

DOI: $10.31258 /$ ijebp.v3n2.p52-63 
The data seen in Chart 3 shows a very significant change. The percentage of student results that received very good grades increased, from 2.77 percent in cycle 1 to 8.33 percent in cycle 2, while the percentage of student learning outcomes at less level was no longer available. The percentage of learning outcomes in cycle 2 was at a very satisfactory level and ended at a sufficient level of 8.33 percent. Thus the research action was decided to end in cycle 2.

The results of classroom action research using CIRC steps towards learning Academic Reading and Writing were able to answer the research objectives stated earlier. The application of the modified CIRC steps can actually improve student learning outcomes. Careful classroom management, by dividing students into small groups of three, has been shown to increase students' activity and learning outcomes in writing summaries. The results of the comparison between the value of the Pre Test and the value contained in Cycle 1 and Cycle 2 can be seen in the following Chart:

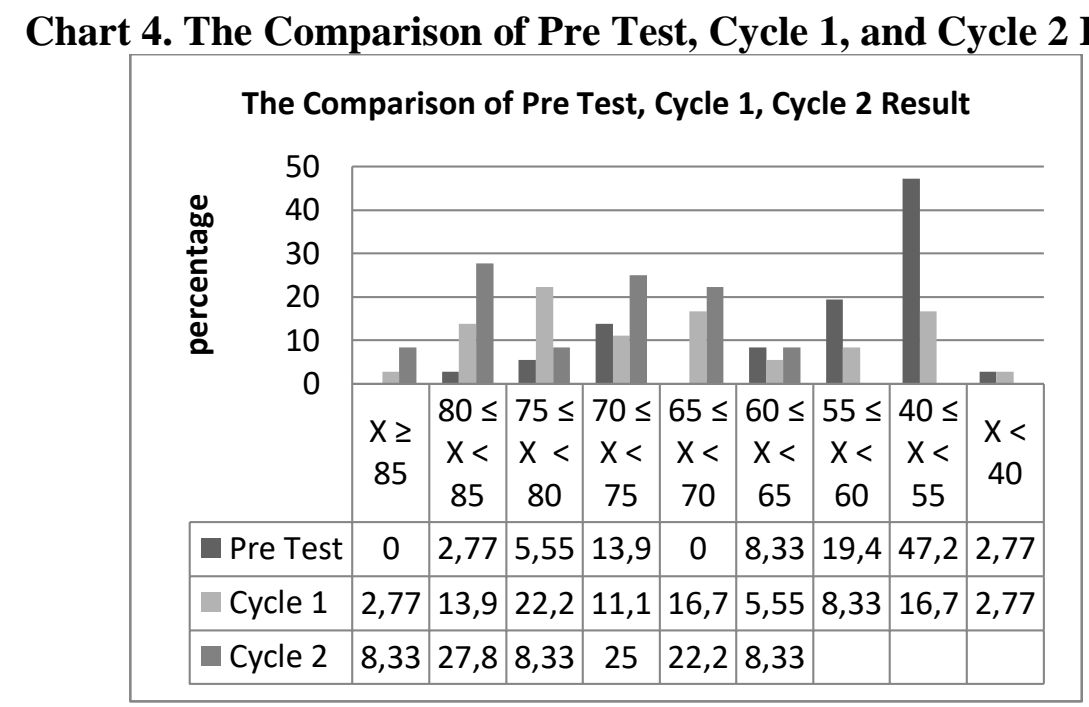

Refers to the result above, the collaborator (Maria S) observed the learning process in two cycles as shown in the chart below:

Chart 5. The observations made by collaborator during the learning took place

\begin{tabular}{|l|l|l|l|}
\hline No. & \multicolumn{1}{|c|}{ Activity observed } & \multicolumn{1}{c|}{ Cycle 1 } & Cycle 2 \\
\hline 1 & $\begin{array}{l}\text { Enthusiastic in joining the teaching } \\
\text { learning process }\end{array}$ & average & good \\
\hline 2 & $\begin{array}{l}\text { The activeness of students in } \\
\text { discussions }\end{array}$ & good & excellent \\
\hline
\end{tabular}

International Journal of Educational Best Practices (IJEBP)

Vol. 3 No. 2 October 2019

ISSN: 2581-0847

DOI: $10.31258 /$ ijebp.v3n2.p52-63 


\begin{tabular}{|l|l|l|l|}
\hline No. & \multicolumn{1}{|c|}{ Activity observed } & \multicolumn{1}{c|}{ Cycle 1 } & Cycle 2 \\
\hline 3 & $\begin{array}{l}\text { Students' fluency in interpreting } \\
\text { readings to group members }\end{array}$ & $\begin{array}{l}\text { Below } \\
\text { average }\end{array}$ & good \\
\hline 4 & $\begin{array}{l}\text { The ability of students to draw } \\
\text { conclusions from the reading } \\
\text { discussed in groups }\end{array}$ & average & good \\
\hline 5 & $\begin{array}{l}\text { The activeness of students in } \\
\text { finding learning resources }\end{array}$ & good & excellent \\
\hline 6 & $\begin{array}{l}\text { The ability of students of writing a } \\
\text { summary }\end{array}$ & good & excellent \\
\hline
\end{tabular}

\section{CONCLUSION}

Based on the results of classroom action research by applying CIRC (Cooperative Integrated Reading and Comprehension) learning steps, conclusions are drawn from the comparison of Pre Test scores, the value of Cycle 1 and Cycle 2 learning outcomes shows a significant increase in learning outcomes. This improvement can be achieved within 4 weeks of the meeting. If in Cycle 1 there were students who received very good grades (2.77\%), then in Cycle 2 students who received very good grades increased to $8.33 \%$, even though the percentage was still small. Besides, the results of observations indicate that the method of grouping has a meaningful contribution to student learning outcomes. If in Cycle 1 group members remain in each meeting, then in Cycle 2 group members change at each meeting. Furthermore, if in cycle 1 the lecturer gives the task of making a summary where the article is determined by the lecturer, then in cycle 2, the article is determined and chosen by each group. This freedom of choice turns out to have a very real impact when viewed from the results of learning in cycle 2 . Thus the CIRC is worth considering to use in Academic Reading and Writing learning.

As a whole, the CIRC learning model is suitable to use in Academic Reading and Writing learning. But if examined further, the acquisition of individual values in the excellent category still needs to be increased in percentage. For this reason, further research is needed, while still using the CIRC learning model but with learning steps that are modified according to the character of the student taking the course, or with other methods that can improve the individual abilities of students in Academic Reading and Writing courses. 


\section{REFERENCES}

Aqib,Zainal., Jaiyaroh, Siti., Diniati, Eko., Khotimah, Khusnul. (2009). Penelitian Tindakan Kelas. Bandung: CV. Yrama Widya.

Brown, Doughglas H. and Priyanvada Abeywickrama. (2010). Language Assessment. 2nd Edition. New York: Pearson Education, Inc.

Chamisah. (2013). An Analysis on the Advantages of Cooperative Learning ApproachinTeachingWriting.Retrieved from (https://www.researchgate.net/publication/322704565_AN_ANALYSIS_ON_THE_ ADVANTAGES_OF_COOPERATIVE_LEARNING_APPROACH_IN_TEACHI NG_WRITING

Durukan, Erhan. (2010). Effects of CIRC Technique on Reading-Writing Skills. Educational Research and Reviews Vol. 6(1), pp. 102-109, January 2011. Turkey: Department of Turkish Education, Faculty of Fatih Education, Black Sea Technical University.

Harmer, Jeremy. (1991). The Practice of English Language Teaching. London: Longman

Hefferman, James, A.W., and John, E. Lincoln. 1994. Writing A College Handbook. New York: W.W Norton Company.

Jordan, RR.(1999). Academic Writing Course. England: Pearson Education Limited.

Kunandar. (2010). Penelitian Tindakan Kelas. Jakarta: Rajagrafindo Persada.

Nunan, David. (1999). Second language Teaching and Learning. Boston: Heinle \& Heinle Publishers.

Oshima, Alice dan Ann Hogue. 1997. Introduction to Academic Writing. 2nd Edition. New York: Longman.

Oshima, Alice dan Ann Hogue. (2007). Introduction to Academic Writing. 3rd Edition. New York: Pearson Education, Inc.

Pardede, Parlindungan. (2017). Integrated Skills Approach in EFL Classrooms: A LiteratureReview 1 Retrieved from (https://www.researchgate.net/publication/332607443_IntegratedSkills_Appr oach_in_EFL_Classrooms_A_Literature_Review_1).

Phenix, Jo. (1990). Teaching Writing. USA: Pembroke Publishers Limited.

International Journal of Educational Best Practices (IJEBP)

Vol. 3 No. 2 October 2019

ISSN: 2581-0847

DOI: 10.31258/ijebp.v3n2.p52-63 
Rooks, George M. (1999). Share Your Paragraph: Interactive Approach to Writing. USA: Prentice Hall Regents

Sanjaya, Wina. (2010). Strategi Pembelajaran Berorientasi Standar Proses Pendidikan. Jakarta: Prenada Media Group.

Shoimin, Aris. (2014). 68 Model Pembelajaran Inovatif dalam Kurikulum 2013. Yogyakarta: Ar-Ruzz Media.

Suprijono, Agus. (2011). Cooperative Learning: Teori dan Aplikasi PAIKEM. Yogyakarta: Pustaka Fajar.

Uno, Hamzah, and Nurdin Mohamad. (2012). Belajar dengan Pendekatan PAILKEM. Jakarta: Bumi Aksara.

Wiriaatmadja, Rochiati. (2005). Metode Penelitian Tindakan Kelas. Bandung: PT. Remaja Rosdakarya. 